特集論文「ヒューマンエージェントインタラクション（ HAI $) 」$

\title{
知的会話処理における連想応答手法
}

\section{Association Reply Method for Intelligent Conversation Processing}

\author{
$\begin{array}{ll}\text { 吉村 枝里子 } & \begin{array}{l}\text { 同志社大学 理工学部 } \\ \text { Faculty of Science and Engineering, Doshisha University } \\ \text { eyoshimurae Eriko }\end{array} \\ & \text { eydy.doshisha.ac.jp }\end{array}$ \\ $\underset{\text { Imono Misako }}{\text { 芋野美紗子 }} \begin{aligned} & \text { 同志社大学大学院 } \\ & \text { Graduate School of Engineering, Doshisha University }\end{aligned}$ \\ mimono@indy.doshisha.ac.jp \\ $\underset{\text { Tsuchiya Seiji }}{\text { 土屋成司 }}$

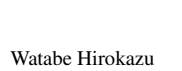 \\ (同上) \\ stsuchiyemail.doshisha.ac.jp \\ (同上) \\ hwatabe@mail.doshisha.ac.jp
}

keywords: conversation, discourse relation, sentence generation, association ability, commonsense judgement

\begin{abstract}
Summary
This paper proposes a response autonomous production method on chatting system for intelligence conversation. An autonomous response method needs some rules for fixed pattern talking and application ability for new expression. A response must make autonomously based on understanding of natural language sentence. So, it needs a mechanism of humanistic association and amphiboly based on grammar and rule of conversation. This paper explains a mechanism of concept association and commonsense judgement and proposes a association response method based on commonsense using the mechanism that is unrealizable only with statistical processing. The proposed response method are place association method, adjective association method and change topic association method based on place information getting from conversation situation. And then there was able to achieve an accuracy of $80 \%, 74 \%$ and $71 \%$.
\end{abstract}

\section{1. 導 入}

近年, 機械は我々の生活・社会と密接に関与し, 必要 不可欠な存在となりつつある．弚のため，機械の目指す べき姿は「人と共存する機械 (ロボット)」だと言えるだ ろう .この夢は, 二足歩行ができる , 走ることができる , 踊ることができるなど身体能力に長けたロボットが数多 く開発されたことにより，弚の一部か実現されつつある． 今後，ロボットが真に人と共存するためには，優れた身 体能力を持ったロボットに「知能」を持たせることが重要 になる．機械がスムーズな会話を行うことにより，人と 円滑なコミュニケーションがとれる知能ロボットの実現 が可能となる. 光こで知能ロボットの自律的応答が今後 の課題とされている . 自律的応答は人間にとって容易だ が，機械には非常に困難となる．弚れは，機械はあらか じめ定められた動作に対応することはできるが，樣々な 状況に対応する応用力には乏しいからである . 自律的応 答には決められたルールに加え，新たな表現や思考に対 応する応用力が必要となる。しかし, 兴のためには, 自 然言語を理解し，応答を自律的に判断し，応答表現を組 み立てなければならない．よって，文法や会話のルール の基礎的知識を持ち合わせた上で, 言語の曖昧性や人間
の連想能力に対応した機構を組み立てる必要がある．

会話のルールに特化した応答処理手法の研究として， あらかじめ決められたパターンに沿って会話を展開す るタスク型会話がある.これは, 目的となるタスクを達 成するために会話を誘導し，話題を制御する．事務的な 作業を行う際に非常に有効であり，例えば DARPA プロ ジェクトの航空券案内システム DARPA ATIS[Kaufmann 90, Kaufmann 91, Kaufmann 92] , 列車発車案内システム TRAINS[H.Kauts 86], 旅館予約システム [飯田 06] , 秘 書システム[谷垣 95]等, 目的に沿った会話システムか開 発されている.これらのシステムは会話状態を遷移图と して把握し , タスクに必要な情報を的確に得るために有 効な会話ルールを展開し, 弚れ以外の話題は受け付けな いことで害用化されている，もちろん，タスクを達成す るためだけに会話を行うため, タスク以外の話題や，登 録されていない語に対応することはできず, 杂隹談のよう な話題の展開には非常に弱い.

杂隹談型のシステムとして，例えば対話システムの一つ である Eliza[J.Weizenbaum 65]がある .これは，相手か ら会話を引き出すことを目的としたカウンセラーシステ ムであった . 基本的にEliza が生成する応答文はキーワー ドをデータベース検索し，乥れに応じた一般的な質問文 
を返す．また，過去に発言した内容の一部分を記憶し その単語をパターンの応答に組み込む，光のため，ユー ザーのどのような会話にも対応することができ，自律的 応答を行っているように見せかけることができた．しか し，光の会話内容を評価することはなかったため，相手 の発話を理解し, 適切な応答を作成したわけではなかっ た . 結果的に人間との会話であると錯覚させた Eliza に 触発され，後続したチャットシステム (A.L.I.C.E, Ractor, Verbot, Julia etc.) は , 相手の応答を応答パターンとして 学習し，人間とのチャット環境に置かれ続けることで膨大 な応答パターンを保有するように改良されていった . 非 タスク指向型の対話研究は多数 [德久 06, 稲葉 09] 行わ れており，例えば [木村 01] らによる音声対話システムは 膨大な対話例を元に遺伝的アルゴリズムを用いた帰納的 学習によって対話ルールの獲得を行い, ELIZA 型よりも 良い性能を示している.これらは膨大な対話例から会話 を模倣することで応答を生成し，雑談型の会話に強いこ とがわかる．しかし，パターンを学習するだけでは過去 のパターンを模倣するだけであり，機械自身の意図によ り応答することはできない，一見，雑談が可能であるよ うに見えるが , パターン学習のみでは自律的応答には限 界がある

これらの問題を踏まえ，自然な会話を行うために事例 パターン知識ベースの大規模化に加えて，発話文の文法 的・意味的解析に語の出現頻度などの統計処理を活用す る自然言語処理の研究 [河原 06][Maedche 01] がすすめ られてきた .これは文の意図・意味を語の出現の統計的 な観点から捉えようという試みである．つまり，自然言 語処理の主流は, 文の文節や単語間の連結を出現頻度に よる統計処理で処理するものである .これにより，音声 認識やタスク処理型会話における文解析は大きく進歩し た .これにより意味を理解し，知識や常識に基づいて自 律的に応答する基盤ができたといえる．

弚こで本論文では，従来の自然言語処理や膨大な事例 パターンだけでは補いきれない，言語の曖昧性や人間の 連想能力に対応した機構を組み込み，知識や常識に基づ いて応答する手法について提案する．本論文では特に連 想や常識といった, 自律的な会話の重要な要素となる構 造について議論する. 光して, 光の応用方法としての連 想応答手法の提案について説明を行う．これにより常識 に基づいた連想を行い，より自律的で応用力に富んだ応 答を行う方法の提案を行う.

杂隹談型対話システムにおける関連研究として文献[江頭 12][高柳 11][柴田 09] が挙げられる .これらは本論文の ように, タスク処理型とは異なり分野依存性が低い、文 献 [江頭 12] は Web 上の情報を元に質問応答などの技術 を用いて対話を行い，強化学習を用いることで適切な対 話戦略を獲得している．対話を重ねることで話題の流れ を学習させ，対話戦略を練ることでユーザーが好ましい と感じる会話を選択できるという知見は興味深い．しか
し，同時に話題選択の際に人間が発話した内容に基づい た連想は行っておらず，これによりユーザーが悪い印象 を持つ可能性があることも示唆している．本論文では人 間の発話内容から連想応答する手法について提案するこ とでこの点についての解決方法を提示できると考えられ る.文献 [高柳 11] はペット型ロボットを想定し，質問 応答・常識知識獲得/利用・吉凶判断・スクリプト対話・ 定型応答の機能を備えた対話システムを提案している 特に本論文と関連のある常識知識については, 対話を重 ねることで常識知識を獲得し，光の知識を三段論法を用 いて推論し応答としている.ただ , ここでの常識知識は 対話によって得られる論理的包含関係のみを扱っており， 本論文のように知識自体の体系化や少の知識の意味的連 想能力にまて踏み込むことについては述べられておらず， 話に広がりを持たせるのが難しい，また，文献 [柴田 09] は広い対話領域での自由対話を実現し，タスク処理型会 話システムと Eliza 型自由対話システムとの中間に位置 する対話システムを提案している．これはユーザー発話 に対する応答として適切な文を Web 上より検索し , シス テム発話としてユーザーに提示する．発話同士の話題の 繋がりに関する表層的結束性とユーザー発話からの連想 のし易さと情報的価值を近似した意味的整合度という二 つの選択基準を用いて表層的にも意味的にも自然で意味 のある発話を生成している点は非常に興味深い，特に意 味的整合性という連想能力を用いた基準により候補文を 選択している点は，本論文のように対話において意味的 な連想能力が必要であるという観点において一致してい る、ただ , 過去に書かれた Web 上の文書の中から候補文 を検索するため，直前の会話に関連はしているが直接的 な話題内容ではない候補文も多く，タスク処理型と Eliza 型の良点と共に悪点も継承している面があると考えられ る.また，本論文では常識的観点を導入し，各観点にお ける連想能力を用いることでより内容に沿った連想を行 う手法を提案する。

\section{2. 連想メカニズム}

人間は受け取った情報を適宜に解釈することができる． これは，言語に関する基本的な知識を蓄積し，経験上で 培つた語概念に関する常識を持つからである．常識的な 判断能力を持つためには語の概念化，すなわち，ある単 語に対して関連のある概念を想起する能力が重要な役割 を果たしていると考えられる .このような言葉に関する 常識的な判断能力を持つために，語に関する知識を理解 する必要がある .

乥こで，人間が持つ語に関する知識をモデル化し，機 械に理解させる.このことで, 人間の会話の仕組みと類 似した会話機構ができると考えられる．この考え方に基 づいて概念連想と常識判断を行う機構を構成する．

概念連想は言葉 (概念) に関する汎用的な知識を連想 
し, 常識判断は場所・時間・感覚などの樣々な常識的観 点における言葉を常識的に判断する。よって，概念連想 は，基本的な語の関係を定義するシステムによって構成 し，常識判断は各々の常識的観点独自の連想を行うシス テムによって構成する.

\section{$2 \cdot 1$ 概 念 連 想}

概念連想は，基本的な語の関係を定義するシステムに よって構成する . 日本語の語彙を体系づけた NTT シソー ラス [池原 97] や同義語・類義語辞書も概念連想に必要な システムとなる .

機械が人間らしい概念の連想を行うためには, 単語間 の意味的な類似性を定量的に示す必要がある . 同義・類 義・包括関係だけでなく, 共起関係や部分関係兴の他常 識に関わる体系化されていない関係が存在する . 乥こで， 人間の常識的な感覚に近い概念連想を行うため, 単語間 の意味的な類似性を定量的に表現する必要がある．

この必要性に鑑み, 概念間の関係性について [岡本 01] や[渡部 06] らによる研究がおこなわれてきた . [岡本 01] らは人間の連想実験によって収集したデータを元に乥の 頻度情報や確率から概念間の類似性を定量化(概念数 660 語) し，[渡部 06] らは辞書や新聞を元に，大規模なデー 夕の頻度情報や確率より概念間の類似性を定量化 (概念 数 34000 語) している. 本論文ではより多樣な連想を行 うため，[渡部 06]らによる手法を利用する．

概念ベースは, 複数の電子化辞書などから各見出し語 を概念，光の見出し語の説明文中の自立語を概念の属性 として，機械的に自動構築された大規模なデータベース である.本研究では, 機械的に構築した後, 人間の感覚 からは不適切である属性を削除し，必要な属性を追加す る自動精錬処理を行った概念ベース（概念数約 9 万） [奥 村 07] 利用している.

初期の概念ベース (基本 CB) [笠原 97][川島 05] は， 約 3 万 4 千の概念表記 $A$ と光の属性 $a_{i}$ 及び重み $w_{i}$ を 複数の国語辞書の語義文から自動的に獲得した .これは 辞書の見出し部の単語を概念表記, 語義文に含まれる自 立語を属性として抽出し，乥れらの属性の重みは光の属 性の出現頻度を基に付与する .さらに, 属性の自己参照 による新たな属性の追加，及び不要な属性の統計的な除 去からなる精錬を行うことによって概念べースを機械構 築している。

概念ベースにおいて，任意の概念 $A$ は，概念の意味特 徵を表す属性 $a_{i}$ と，この属性 $a_{i}$ か概念 $A$ を表す上でど れだけ重要かを表す重み $w_{i}$ の対で表現される . 概念 $A$ の属性数を $N$ 個とすると，概念 $A$ は以下のように表す ことができる．ここで，属性 $a_{i}$ を概念 $A$ の一次属性と 呼ぶ。

$$
A=\left\{\left(a_{1}, w_{1}\right),\left(a_{2}, w_{2}\right), \cdots,\left(a_{N}, w_{N}\right)\right\}
$$

概念 $A$ の一次属性 $a_{i}$ は概念ベースに定義されている

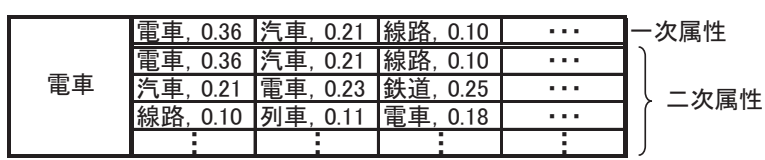

図 1 概念「電車」を二次属性まで展開した場合の例

概念としているため, $a_{i}$ からも同樣に属性を導くことが できる . $a_{i}$ の属性 $a_{i j}$ を概念 $A$ の二次属性と呼ぶ ．概念 ベースにおいて「概念」は $n$ 次までの属性の連鎖集合に より定義されている. また，各概念表記に対し平均 30 属 性が付与され，属性に付与される重みは产の概念表記に 対する重要度であり, 各概念表記について, 兴の総和が 1.0 となるように正規化されている。概念「電車」を二次 属性まで展開した樣子を図 1 に示す。

概念ベースに存在する概念に対し，光の概念集合にお ける各概念の重要性, 概念ベース IDF 值を計算すること ができる . IDF 值は情報検索の分野で用いられる単語重 み付け手法であり，稀に出現する語は重要であるという 観点から重み付けされた対数文書頻度の逆数である.こ こでは以下の方法て概念べース IDF 值を求める.

（1）概念ベース内の属性全てを対象とし，概念連鎖に よって三次まで展開する .

（2）全概念数を $N_{A l l}$ とする．また，全概念を三次ま で展開した属性群 (文書空間) 内での概念 $t$ の出現数 を $d f(t)$ とし, $i d f(t)$ を以下の式で計算する .

$$
i d f(t)=\log \frac{N_{A l l}}{d f(t)}
$$

汎用的な辞書の知識である概念べース内で使用頻度の 低い語は日常会話でもあまり使用されない，光こで，IDF 值を用いると，概念ベース内で使用頻度の低い語として 雑音を除くことができる．本来，IDF 値とは出現頻度の 低い語の值が大きく，重要である，という観点で重み付 けされるものであるが，ここでは,「稀に出現する語は一 般的でない」という観点で，弚のような語を抽出するた めの単なる「計算式」として用いる.

関連度は，概念と概念の関連の強さを定量的に評価す る. 具体的には, 対象となる二つの概念において, 概念 連鎖により概念を展開し，最も対応の良い一次属性同士 を対応づけ，光れらの一致度合いを計算することにより 算出される. 本研究では動的関連度計算方式[荒木 07][渡 部 06]を用いた。

概念関連度は $0.0 \sim 1.0$ の值をとり，值が高いほど関 連の深い語であることを意味する．

概念 $A$ と概念 $B$ に対して関連度計算を行った例を表 1 に挙げる。

概念ベースと関連度計算は次の手法で精度評価を行う．

まず，任意の概念を基準概念 $X$ とし，人間が判断し て非常に高い関連があると考えられる概念 $A$, 概念 $A$ ほどではないが，概念 $X$ に対して関連があると考えら れる概念 $B$, 弚して概念 $X$ に対して無関連だと考えら 
表 1 関連度計算の例

\begin{tabular}{clc}
\hline 概念 $A$ & 概念 $B$ & 関連度の值 \\
\hline 花 & 桜 & 0.224 \\
花 & 車 & 0.001 \\
天気 & 晴れ & 0.446 \\
天気 & 学校 & 0.002 \\
\hline
\end{tabular}

表 $2 X-A B C$ 評価用データ

\begin{tabular}{|c|c|c|c|}
\hline$X$ & $A$ & $B$ & $C$ \\
\hline 飲食店 & 食堂 & 客 & 得意 \\
\hline 飲み物 & 飲料 & 液体 & 選択 \\
\hline 病人 & 患者 & 治療 & 磁石 \\
\hline
\end{tabular}

れる概念 $C$ を一組とするデータを準備する .このよう な4つの見出し語を一組として構成するデータセットを $X-A B C$ 評価用データ (表 2) と呼ぶ。 概念 $X$ と概 念 $A$ との関連度を $\operatorname{Do} A(X, A)$, 概念 $X$ と概念 $B$ との 関連度を $D o A(X, B)$, 概念 $X$ と概念 $C$ との関連度を $D o A(X, C)$ とする. 光して表 2 で示したデータセット 500 組での $\operatorname{Do} A(X, C)$ の平均を $\operatorname{AveDoA}(X, C)$ とし て , 次の条件によって評価を行う.( $m$ はテストセットの 総数であり, $m=500$ )

$$
\begin{gathered}
\operatorname{Do} A(X, A)-\operatorname{Do} A(X, B)>\operatorname{AveDo} A(X, C) \\
\operatorname{Do} A(X, B)-\operatorname{Do} A(X, C)>\operatorname{AveDo} A(X, C) \\
\text { AveDoA }(X, C)=\frac{\sum_{i=1}^{m} \operatorname{Do} A\left(X_{i}, C_{i}\right)}{m}
\end{gathered}
$$

概念 $X$ と関連がない概念 $C$ との関連度 $D o A(X, C)$ は， 本来 0.0 となるのか理想だが, 関連度計算方式の特性上, 微小な值が算出される. とこで概念 $C$ との関連度を誤差 とみなし , 光の平均 Ave Do $A(X, C)$ をテストデータ全体 での平均誤差とする. 光して $D o A(X, A), D o A(X, B)$ ， $D o A(X, C)$ 光れ攵れの関連度の間に平均誤差以上の差 が存在していれば, 正当な数值として正解と見なす . こ の評価を全ての組に対して行った上で, 正解となったテ ストデータの組の比率を概念ベースの精度とする . 本研 究では 85.6\%の精度 [芋野 11] を得た概念ベースを使用 する

\section{$2 \cdot 2$ 常 識 判 断}

人間は曖昧な情報を受け取った場合にも，適宜に解釈 し適切に会話を進めたり，行動をとることができる．これ は，人間が長年の経験から，言語における知識を蓄積し， 产の基本となる概念に関する常識を確立しているからで ある.このことから，コンピュータに常識を与え，判断さ せる研究がおこなわれている [秋葉 04][村本 11] . また， 常識をデータベース化することが必要であるとの認識か ら，近年 MIT による Open Mind Common Sense[MITb] や炎れを体系づけた ConceptNet[MITa][Havasi 07] など の研究活動が活性化しつつある . しかし日本語において
は質量ともに不足し , 未だこれらの常識収集プロジェク 卜は進行途上にある．また，常識すべてを網羅するデー タベースを作成すること，および光れらすべてを機械的 に体系づけることは非常に困難である．

光こで本研究では常識知識の体系づけと情報収集を分 離し, 質量ともに高い常識知識の構築を目指すメカニズ ムを採用する [渡部 04][杉本 03] . 本メカニズムでは, 常 識知識は複数の観点 (量, 時間, 感覚, 感情, 場所など) に類別し体系づける．

人間は経験によって培われた「知識」と既に持っている 知識を経験によって応用する「応用力」によって「常識」 を確立している．本研究で用いる常識知識ベースにおい て, 構成する知識は各種常識判断特有の知識を表, 分類 木, ルールなどの知識表現方式により定義し，少数の代 表的な語と光れに関する知識を表現する.この各種の判 断に必要な特有の知識が, 経験によって培われる「知識」 に相当する．一方，各種常識判断機構では基本的な語の 関係を定義する概念連想が組み込まれている．概念連想 は言葉に関する汎用的な知識を有し，辞書や新聞記事を 元に大規模なデータから構築されている.この概念連想 は「応用力」に相当し，各種の判断に必要な特有の少数 の代表的な知識を一般的な知識によって拡大し，応用す るための手段として用いる [土屋 02] . 本節では常識知識 の観点の中でも感覚 , 場所についてシステム化したもの を説明する．

感覚という常識の観点として [渡部 04] の感覚判断シ ステムを用いる。これは名詞に対して，人間が常識的に 想起でき，特徵付けられる感覚に関する語を取得するシ ステムである．この「感覚」とは五感 (視覚・聴覚・嗅 覚・味覚・触覚) の刺激によって得られる感覚を指す.感 覚判断システムは名詞と炎の特徵である「感覚」の関係 を日常的な名詞の知識ベース (感覚判断知識ベース) を構 築することによって明確にし，必要な感覚語を取得する．

感覚判断知識ベースはシソーラス構造をとる．感覚に 関する語という観点で見た場合，名詞には午の名詞のグ ループが持つ感覚と炎の名詞固有の感覚の 2 種類がある. 感覚判断知識ベースはこの 2 種類の感覚を継承できるよ うにするためにシソーラスのリーフとノードの関係を用 いて構築されている.具体的には，日常よく使用される 680 語をシソーラスのリーフ (代表語) として登録し, 光 れ光れに炎の語固有の感覚を付与している．また，㫕れ らをグループ化しシソーラス構造をとるための語をノー ド (分類語) として 153 語登録し, そのグループが持つ 感覚を付与している.この感覚判断知識ベースは図 2 の ような構造を用いている。

また汎用知識である概念ベースとシソーラスを用いる ことで, 構築した感覚判断知識ベースにない語 (未知語) に対しても「感覚」を想起することができる．未知語に 対して感覚を付与する場合，分類語としての感覚と光の 未知語固有の感覚を付与する処理を行う.これは未知語 


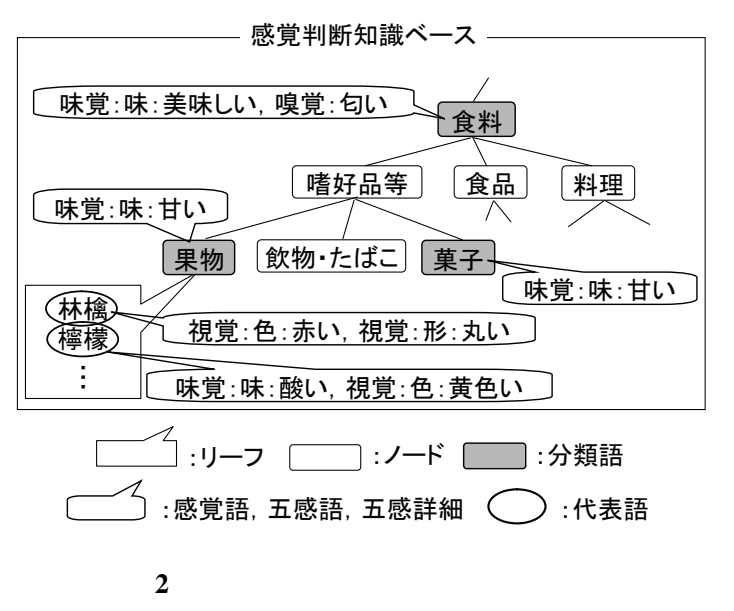

表 3 未知語と代表語 680 語 (一部) の関連度計算例

\begin{tabular}{|c|l|}
\hline 未知語一代表語 & 関連度 \\
\hline パンダ一熊 & 0.266 \\
\hline パンダー牛 & 0.220 \\
\hline パンダー宝石 & 0.149 \\
\hline パンダー本 & 0.047 \\
\hline
\end{tabular}

に対して，関連度計算を用いて感覚判断知識ベース内に 含まれる高い関連度を持つ代表語を取得し，炎の語群の 属するシソーラスのノードから分類語としての感覚を取 得する .

例えば「パンダ」の場合，680 語の代表語（シソーラ スのリーフ）と「パンダ」との関連度計算を行う．この とき，最も高い関連度を持つ代表語（表 3 の「熊」）を取 得する . 代表語には感覚語があらかじめ付与されてい るが，これは光の語固有の感覚語となる．弚のため，こ の代表語に付与されている感覚語を兴のまま取得するの ではなく，代表語が属する分類語（シソーラスのノード） に付与されている感覚語を取得する . 例の場合，「熊」が 属するノード「動物」に付与されている「暖かい」を取 得する .

これに加えて , 未知語固有の感覚語を取得する . 概念 ベースを用い，未知語の一次属性に現れる感覚語を，概 念ベースの特徵を利用した自動精錬法 (詳細は文献 [土屋 02] を参照されたい) を行った後 , 未知語固有の感覚とし て取得する。

表 4 に未知語固有の感覚取得の例を示す . 表 4 の未知 語「パンダ」の例では, 兴の属性から「白・黑・大きい」 などを末知語固有の感覚として取得することができる． 感覚判断システムを用いた例を表 5 に示す.

表 4 未知語固有の感覚取得の例

\begin{tabular}{c|l}
\hline 概念 & 属性 \\
\hline パンダ & 熊, 動物, 白, ライオン , 自然 , 生きる, \\
& チベット, ぬいぐるみ, 足 , 黒 , 山 , 中国, \\
& 大きい, 林, 竹 , $\cdots$ \\
\hline
\end{tabular}

表 5 感覚判断システムの使用例

\begin{tabular}{c|l}
\hline 概念 & 感覚語 \\
\hline 林檎 & 赤い, 甘い, 丸い \\
夕焼け & 眩しい, 赤い, 美しい \\
騒音 & 煩い \\
\hline
\end{tabular}

表 6 場所判断知識ベースの一部

\begin{tabular}{|c|c|c|}
\hline 場所語 & 場所主体語 & 場所目的語 \\
\hline \hline 神社 & 神主, 鳥居 , $\cdots$ & 参拝 , 祈願 , $\cdots$ \\
\hline 病院 & 医者 , 患者 , $\cdots$ & 診察 , 入院 , $\cdots$ \\
\hline
\end{tabular}

また，場所という常識の観点として [杉本 03] の場所 判断システムを用いる.これは場所を表現する語から光 の場所に存在する人や物 , 行われる事象を想起する .こ こで，場所とは，「神社」や「病院」のように，ある人・ 物・事象が実際に存在する具体的な場所を表す語とする。

場所判断システムは, 場所を表現する語 (以下, 場所語 と呼ぶ）を収録した知識ベース（以下，場所判断知識ベー スと呼ぶ）と，未知語処理手法により構成されている．

場所判断知識ベースには, 弚の場所に存在する人や物 と, 兴の場所で行われる事象が場所語と関連付けられて 登録されている．前者の人や物を場所主体語, 後者の事 象を場所目的語と呼ぶ. 表 6 に具体例を示す.

以下，場所判断知識ベースに登録されている場所語を 代表語と呼ぶ：これら代表語と場所主体語，場所目的語 の関係を効率よく表現するために，場所判断知識ベース はシソーラス構造をとる .

代表語をシソーラスのノードまたはリーフとして登録 し，光れ光れのノード，リーフの属性として場所主体語 と場所目的語が登録されている.場所語に該当する部分 は ,ノード 120 語 , リーフ 7825 語であり，場所語に関係 するリーフ7825 語のうち, 全てのリーフをチェックした 結果，本質的に場所に関する語が 443 語であった .よっ て, 場所判断知識ベースには分類語 (ノード) 120 語 , 代 表語 (リーフ) 443 語が登録されている.具体例を図 3

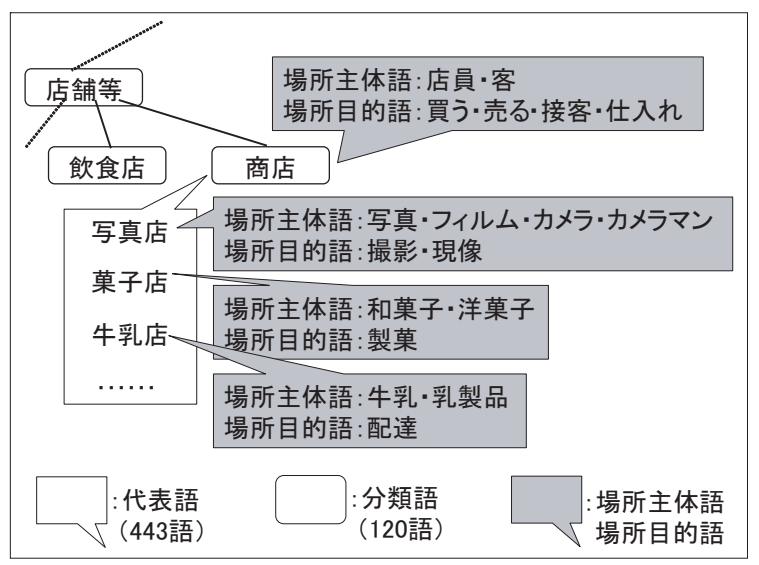

図 3 場所判断知識ベースの具体例 
表 7 場所判断システム使用例

\begin{tabular}{|c|c|c|c|}
\hline 入力 & 場所語か & 場所主体語 & 場所目的語 \\
\hline 牛乳 & $x$ & - & - \\
\hline 本屋 & $\bigcirc$ & $\begin{array}{c}\text { 客, 店長, } \\
\text { 本, 杂倠誌, } . \text {. }\end{array}$ & $\begin{array}{c}\text { 売る，買う， } \\
\text { 接客，‥ }\end{array}$ \\
\hline 時計 & $x$ & - & - \\
\hline
\end{tabular}

に示す．

分類語 (ノード) と代表語 (リーフ) は継承関係にあ る. 分類語に付与された場所主体語, 場所目的語は代表 語に継承される．代表語は光れ光れ固有の場所主体語・ 場所目的語を持っており，光の固有の情報と分類語から 継承された情報を含めて場所主体語・場所目的語を出力 する

ある未知語が場所語であるか否かの判断は, ある未知 語 $X$ か場所判断知識ベースに登録されている分類語 $P$ に 対して意味的な関連性が極めて強い場合, すなわち, 未 知語 $X$ と分類語 $P$ との関連度が定義した閾値 (実験によ り検証された）を越える場合，ある未知語 $X$ は場所語で あると判断する．これを未知語処理手法と呼ゔ．

また，場所語であると判断された語について，場所主 体語と場所目的語を想起する.場所語のうち既知語（代 表語) については, 弚の語から想起される場所主体語と 場所目的語があらかじめ場所判断知識ベースに登録され ているため容易に想起を実現できる . 未知語については， 未知語処理手法により関連の強い分類語がわかる. 产の 分類語に属する代表語との関連度計算を算出し, 最も関 連が強い代表語に未知語を対応付ける. 光して, 対応付 けられた代表語に登録されている場所主体語, 場所目的 語との関連度を算出し, 兴の值があらかじめ設定したあ る閾値 (実験により検証された) を越える場合のみ，未知 語に関連付ける場所主体語，場所目的語として取得する。 このシステムの使用例を表 7 に示す.

\section{3. 文の意味理解}

自律的な会話を行うためには, ユーザーの会話文の意 味を理解しなければならない，しかし，機械が人間のよ うに文の意味を理解することは本質的に難しいため, 理 解したように「見せかける」必要がある.弚こで, 文の各 要素及び単語が持つ役割を分類することで明確にし，機 械が文の意味を理解したということを示す．

各単語の意味は辞書や連想機能によって明確にするこ

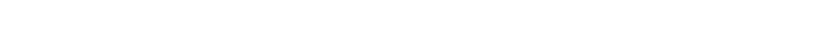
い」）．文を理解するには，更に弚れ光れの単語がどのよ うな状態か，を把握することが必要である。

そこで，文における乥れ光れの単語の役割を区別する ための情報フレームを作成する.本論文では入力文 (単 文) $6 \mathrm{~W} 1 \mathrm{H}+$ 用言 (verb) のフレームに分割して格納す る手法を採用した . これは格助詞や文法ルールを用いた，

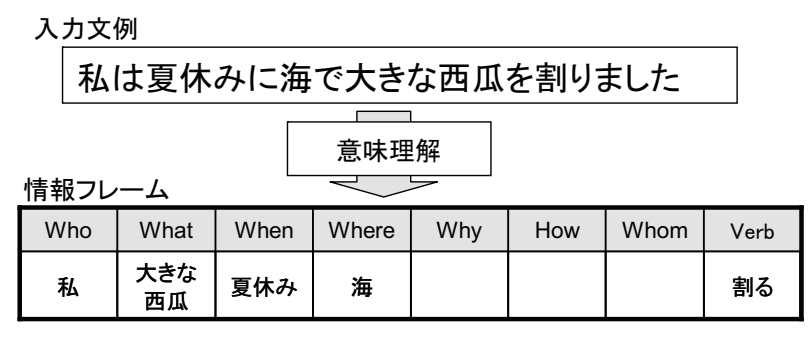

図 4 意味理解の例

\begin{tabular}{|ll|}
\hline USER: & 美術館へ行きました . \\
SYSTEM: & 絵画を見てきたのですか? \\
\hline
\end{tabular}

図 5 場所連想の例

文を理解するための整理手法である [篠原 02] . 例を図 4 に挙げる。

\section{4. 連 想 応 答}

意味理解した文に対し，2 章で説明した常識や連想能 力を踏まえて応答文を生成する.この時, 話者がどのよ うな状態であったのか把握することが必要となる.話者 の状態とは，環境，心情の 2 種類が存在する. 本論文では 前述した常識や連想能力の応用例として, 特に環境 (場 所）に関する情報に起因した連想応答を提案する。

\section{$4 \cdot 1$ 場 所 連 想}

ユーザーの発話文内の場所に関する語 (場所語) を元 に，話者の行動(何を行ったか)を連想して応答を行う方 法を提案する.例を图 5 に示す．例では，場所語「美術 館」で行われること「絵画を見る」を連想し，光の行動 について問う,という形式を示す。

ユーザーの入力文を意味理解すると，Where フレーム に「美術館」，Verbフレームに「行く」か格納される，光 の入力文より，弚の「場所」ならば一般的に「何を行う か」を連想し応答を行うため, What フレームが空欄であ る入力文に対して処理を行う.

乥こで, 場所連想を行う入力文の要件を, What フレー ムが空欄であること，Where フレームが空欄でないこと， 用言フレームが後述する場所動詞知識ベースに存在する こと，とする．

場所に対する話者の行動を問う場合，光の入力文が「場 所を訪れる」という内容を含み，弚れが主内容である必 要がある.例えば，「遊園地を所有している」のように， 場所には関係するが訪れていない文，「公園で骨折した」 のように, 動詞に重要な意図がある文は除く「遊園地を 所有している」ならば，弚の場所には行ったことにはな らない．また，「公園で骨折した」ならば，弚の場所での 行動を連想した応答をするより，「骨折」という重要な情 報について問うのが適切だと考えられる . 
表 8 場所動詞知識ベース (13 語)

行く, 訪れる, 訪問する, 出発する, 出かける, 連れて行く, 飛び立つ, 帰る， 帰宅する，戻る，近づく，入る，来る

表 $9 「$ 美術館」に対する場所主体語と場所目的語の取得例

\begin{tabular}{|c|c|c|}
\hline 場所語 & 場所主体語 & 場所目的語 \\
\hline 美術館 & 周刻 , 絵画 , 館長 , & 展示, 閲覧 , \\
& 工芸 , 美術品 , 版画 & 鑑賞 , 見る \\
\hline
\end{tabular}

そこで, 場所動詞知識ベースには「行く」や「訪れる」 のように場所を訪れたことを主内容とする動詞 (二格と ヨ格の目的格を取り，且つ動詞の目的語に場所語を入れ た際，弚の文が適切な文となる) を格納した .この場所動 詞知識ベースを表 8 に示す .

これらの要件を満たした入力文に対し，場所連想を行 う.まず, Where フレームの語 (場所語) を場所判断シ ステムに入力として渡し，場所主体語・場所目的語を取 得する「美術館へ行きました」の場合の例を表 9 に示す．

次に，場所主体語から「館長，駅員」などの人物に関わ る語を省く . 場所主体語の人物ノードをランダムにピッ クアップ調査した結果, 応答生成に向かないと判断した. これは話者の行動を連想して応答に用いる場合，乥の場 所に存在する人物 (館長, 駅員) は日常会話ではあまり使 用されにくいからと考えられる．このため，NTT シソー ラス [池原 97] を用い, 場所主体語から「人物」ノードに 含まれる語を除く.

また，場所目的語から「公開，展示」などの受身を取る 頻度が高い語を省く．受身を取る頻度が高い語は話者の 行動を表す語となりにくいためである．このため，Web から自動構築された大規模格フレームシステム [河原 06] を用いて，受身を取る頻度が高い語を除く。これを用い た例を表 10 ，表 11 に示す.このシステムに，用言「展 示」, 名詞「絵画」(場所主体語内で最も「展示」と関連 が深い)を与えると, ガ格・受身で最も多用されることが わかる (表 10 よりカ格が最多，表 11 より光のカ格にお いて受動態が最多であることがわかる）．乥こで，「展示」 は受身で用いられることが多いと考えられるため，この ような語を削除する。

表 12 に表 9 から「美術館」に対する不必要な語を除 いた場所主体語と場所目的語の例を示す。

次に, Where フレームの語 (場所語) と不必要な語を

表 10 格に対する頻度数

\begin{tabular}{|c|c|c|c|}
\hline 名詞 $($ 入力 $)$ & 用言 $($ 入力 $)$ & 格 $($ 出力 $)$ & 件数 $($ 出力 $)$ \\
\hline 絵画 & 展示 & ガ格 & 376 \\
& & Э格 & 267 \\
& & ノ格 & 47 \\
& & カラ格 & 2 \\
\hline
\end{tabular}

表 11 「絵画が展示」に対する態の頻度

\begin{tabular}{|c|c|c|c|}
\hline 名詞 (入力) & 用言 (入力) & 格 (入力) & 態と件数 (出力) \\
\hline 絵画 & 展示 & 力゙格 & $\begin{array}{l}\text { 能動態 } 28 \text { 件 } \\
\text { 受動態 } 348 \text { 件 } \\
\text { 使役 } 0 \text { 件 }\end{array}$ \\
\hline
\end{tabular}

表 12 不必要な語を除いた場所主体語と場所目的語

\begin{tabular}{|c|c|c|}
\hline 場所語 & 場所主体語 & 場所目的語 \\
\hline 美術館 & 周㧡 , 絵画 , 工芸 , & 閲覧，鑑賞， \\
& 美術品，版画 & 見る \\
\hline
\end{tabular}

除いた場所主体語群で関連度計算を行い, 最も関連度が 高い場所主体語を選択する . 同樣に選択した場所主体語 と不必要な語を除いた場所目的語群で関連度計算を行い， 最も関連度が高い場所目的語を選択する。

例を用いて説明すると，不必要な語を除いた場所主体 語群「彫刻, 絵画, 工芸, 美術品, 版画」と場所語「美 術館」をとれ光れ関連度計算した結果，「美術館一絵画」 の関連度が最も高かった . 兴のため, 場所主体語「絵画」 を選択する．このことが, 入力文において空欄であった What フレームを連想したことになる．

更に，この選択した「絵画」と場所目的語「閲覧，鑑 賞, 見る」を光れ攵れ関連度計算し, 結果として「絵画一 見る」の関連度が最も高かった .このため, 連想応答に 用いる語として「絵画－見る」を選択する．

この選択した名詞と用言の組を用いて, 語尾変換を行 い, 適用条件に合致するテンプレートを利用して応答文 を作成する．この手法によって，「美術館へ行きました」 というUSERの入力文に対し「絵画を見ましたか?」や 「絵画を見てきたのですか?」といった連想応答文を作成 する .

\section{$4 \cdot 2$ 形 容 詞 連 想}

疑問文で終わる質問応答だけでは会話は機械によるー 方的な質問に終始し, 人間にとってストレスを感じさせ る要因になると考えられる．乥こで，一般的な感覚によ る共感を示す応答によって产の問題を解消させる．

本節では, ユーザーの発話文内の場所に関する語 (場 所語) を元に，乥こに存在する人や物体を連想し，关の物 体に対する一般的な感覚を応答として用いる方法を提案 する . 存在する人や物か既に入力文に含まれている場合 は, 弚れに対する一般的な感覚を応答として用いる. 光 こで, 入力文を意味理解した際, What フレームに語が存 在するか否かで処理を変更する.

What フレームに語が存在する場合の例を図 6 に示す .

また , What フレームに語が存在していない場合, What フレームに入る語句を連想した上で応答文を生成する .こ の場合の例を図 7 に示す． 


\begin{tabular}{|ll|}
\hline USER: & 草原でタンポポを見ました . \\
SYSTEM: & タンポポは綺麗ですよね. \\
\hline
\end{tabular}

図 6 形容詞連想の例 (What あり)

\begin{tabular}{|ll|}
\hline USER: & 私は博物館へ行きました. \\
SYSTEM: & 周刻は美しいですよね. \\
\hline
\end{tabular}

図 7 形容詞連想の例 (What なし)

What フレームに語が存在していない場合の What フ レームの連想方法は $4 \cdot 1$ 節の手法と同樣である .すなわ ち，場所語の場所主体語から不要語を除き，光の場所主 体語群と場所語で関連度計算を行い，最高関連度を持つ 場所主体語を取得する「博物館」を例にすると，不要な 語を除いた場所主体語「周刻，美術品」などと「博物館」 の関連度を取り, 最高関連度であった「周刻」をWhat レームの連想語として取得する。

What フレームの連想語もしくは What フレームに存在 する語句を用いて更に乥の語句から連想できる形容語を 連想する.これは，一般的な感覚による形容語で形容す ることで，常識的な会話を行うことを目的とするためで ある . 例えば,「赤ちゃんは可愛い」「雪は冷たい」などの 常識的な感覚を用いることにより一般的な感覚による共 感を示すことができると考える

そここで感覚判断システムを用いて形容語を取得する。 また, 補助的にWebから自動構筑された大規模格フレー ムシステムを用い，上位 30 件の形容詞を取得する.「彫 刻」「タンポポ」を例として，連想される形容詞の候補 を表 13 に示す。

次に，取得できた形容語の候補語と What フレームの 語との関連度を計算し, 最高関連度をもつ形容語を決定 する.例の場合「彫刻 - 美しい」「タンポポ-綺麗」の組 が最も高い関連性を示した .このため, 連想応答に用い る語として「周刻 - 美しい」「タンポポ-綺麗」を選択す る.この選択した名詞と形容語の組を用いて, 語尾変換 を行い, 適用条件に合致するテンプレートを利用して応 答文を作成する .

表 13 連想される形容詞の候補

\begin{tabular}{|c|c|c|}
\hline $\begin{array}{c}\text { 任意の } \\
\text { 名詞 }\end{array}$ & $\begin{array}{c}\text { 感覚判断 system } \\
\text { からの連想 }\end{array}$ & $\begin{array}{c}\text { 格フレーム system } \\
\text { からの連想 }\end{array}$ \\
\hline 周刻 & 美しい, & 好き, 詳しい, \\
& 素晴らしい & 有名 , $\cdots$ \\
\hline タンポポ & なし & 好き, 綺麗, \\
& & 大好き,,$\cdots$ \\
\hline
\end{tabular}

\begin{tabular}{|ll|}
\hline USER: & 動物園でパンダを見ました . \\
SYSTEM: & ライオンは見ましたか?
\end{tabular}

図 8 話題転換連想の例

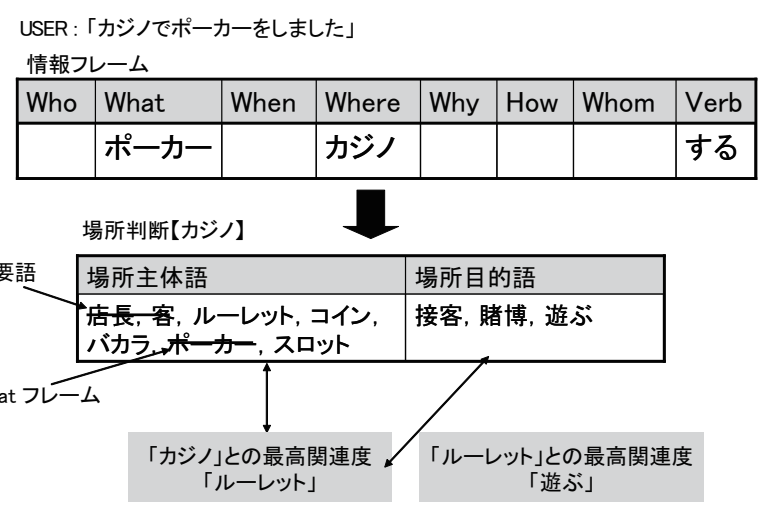

SYSTEM :「ルーレットで遊びましたか? 」

図 9 話題転換連想の処理例

\section{$4 \cdot 3$ 話題転換連想}

$4 \cdot 1$ 節や $4 \cdot 2$ 節の連想方法では, ユーザーの入力文か ら常識的に予測できる行動を連想して応答を行う方法を 説明した。しかし，前述してきたような直接的な受け答 えのみの場合 , 会話は滞りがちになり , 新たな話題へと発 展しづらいと考えられる. 弚こで，会話に摇れを起こし， 会話の流れを起こすことを目的として，本節では，会話 に流れを作りだすため, 入力文の内容から連想し，関係 はあるが異なった話題を行うための応答を作成する．す なわち, 話題転換を行うための連想応答手法を提案する . 話題転換連想の例を図 8 に示す.

例では，ユーザが「パンダを見た」という情報を伝え ているにも関わらず, システムは「ライオンを見たか?」 という情報の応答を行っている.これはユーザの発言に 対する直接的に関係する応答ではない，扱う入力文は入 カ文を意味理解した際に Where フレーム, What フレー ムを含む文とする．

処理例として、「カジノでポーカーをしました」という ユーザの入力文を挙げる (図 9 に示す) .

入力文の場所語「カジノ」の場所主体語から不要語を 除く ( $4 \cdot 1$ 節と同樣) . 不要語を除いた「ルーレット, コ イン , バカラ, ポーカー, スロット」から What フレー ムの「ポーカー」を更に除く .これにより，入力文の場 所語と関連はあるが, 入力文の名詞 (What フレーム) と 同じではない語句を候補として残すことができる．

次に候補語群と場所語「カジノ」の関連度を計算し, 最 高関連度を持つ語を取得する . 例の場合、「カジノールー レット」の組が最も高い関連性を示した .このため, 連 想語として「ルーレット」を取得する.更に, 取得した

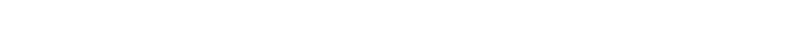
連度を計算し，最高関連度を持つ用言を取得する.この 
表 14 テンプレートパターン

\begin{tabular}{|c|c|}
\hline 適用条件 & テンプレートパターン \\
\hline 用言が & · $\{$ 場所主体語 $\}$ を(に/は) \\
\hline 「動詞」 & 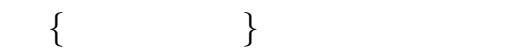 \\
\hline または & 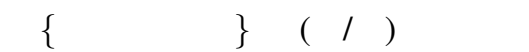 \\
\hline$\ulcorner$ サ変接続」 & $\{$ 場所目的語 $\}$ のですか? \\
\hline の場合 & 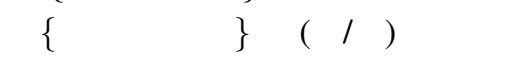 \\
\hline & $\{$ 場所目的語 $\}$ ましたか? \\
\hline 用言が & • $\{$ 場所主体語 $\}$ を(に/は) \\
\hline 形容詞」 & $\{$ 状態語 $\}$ ですよね \\
\hline の場合 & 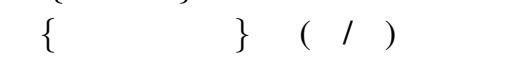 \\
\hline & \{状態語 $\}$ でしたか？ \\
\hline & 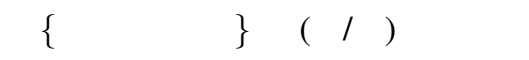 \\
\hline & \{状態語 $\}$ のですか? \\
\hline
\end{tabular}

場合「ルーレットー遊ぶ」の組が最も高い関連性を示し た .これらのことから，話題転換連想に用いる語として 「ルーレットー遊ぶ」を選択する .

この選択した名詞と用言の組を用いて, 語尾变換を行 い, 適用条件に合致するテンプレートを利用して応答文 を作成する．この手法によって,「カジノでポーカーをし ました」というユーザの入力文に対し，「ルーレットで遊 びましたか?」といった話題転換の連想応答文を作成す ることができる

\section{4 応答文テンプレート}

応答文テンプレートとして, 以下の表 14 に示すテン プレートパターンを知識ベース化しておく .

助詞の選択では大規模格フレーム検索を用いる . 大規 模格フレーム検索では名詞と用言の用法を検索すること ができるため，名詞に場所主体語，用言に場所目的語及 び状態語を指定し, 名詞と用言の二語の関係から複数の 用言の用法と頻度を取得することができる．最も高い頻 度をもつ用法を助詞として獲得する。

また，用言の語尾変換は過去形とし，テンプレートに沿 うように動詞を過去形に変換する . 動詞の過去形は,「連 用形」+「た」が基本形であり，上一段活用の「着る」を 例にすると，連用形は「着」となるため「着」十「た」と なる．しかし，五段活用「買う」の場合，連用形は「買 い」になるので,「買う」の過去形は「買い」+「た」とな る「買う」の過去形は「買った」であるので,「買い」を 連用形の音便形を用いて，買っ」と変換する必要がある．

以上のように, 上一段活用動詞や下一段活用動詞では 音便処理は必要ないが, 五段活用動詞については音便処 理が必要となる.五段活用動詞における，過去形とする ための音便の種類を表 15 に示す . 未然形の種類によって 分類される.
表 15 音便の種類

\begin{tabular}{|c|c|c|c|}
\hline 未然形 & 音便 & 変換語 & 具体例 \\
\hline カ, ガ & 个音便 & い & 書く 書い+た \\
\hline サ & イ音便 & し & 探す＼cjkstart探し+た \\
\hline ア ア ラ, ワ & 促音便 & D & 買うか買っ+た \\
\hline ナ,バ, マ & 撥音便 & h & 遊ぶー遊ん+だ \\
\hline
\end{tabular}

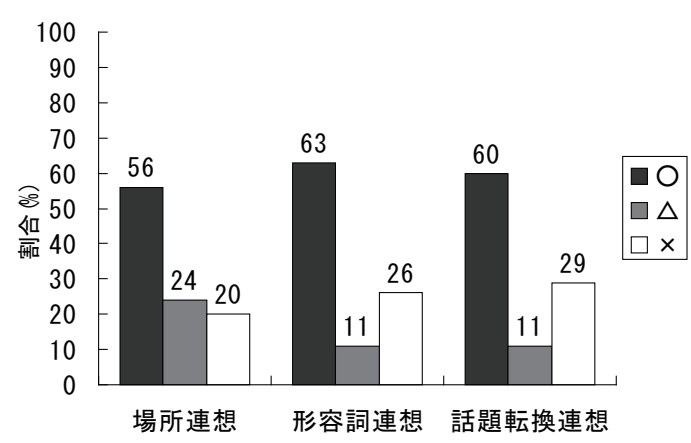

図 10 連想応答評価結果

\section{$4 \cdot 5$ 評 価と考 察}

提案した連想による応答手法が応答文として適切であ るかを評価する、評価データは中学英語テキスト [hor 05, cro 05, sun 05, tot 05 , one 05, col 05] の日本語訳文を 用いる.中学校で学習する英語はコミュニケーションの 基礎を養うことを目標としており，テキストも光れに準 じた基礎的なコミュニケーション会話を多く含んでいる． 兴のため, 基礎的なコミュニケーション会話の指標とし て中学英語テキストより，連想応答の生成条件に合致す る，場所に関する名詞が含まれる会話文（疑問文や命令 文ではない文) を抽出した。場所連想, 形容詞連想, 話 題転換連想光れ光れについて評価を行うため，光れ光れ の連想応答手法の生成条件に合致する 100 文を評価デー タとする . 生成条件に合致しても出力文として必ず成功 するわけではなく，各応答手法において連想機構により システムが自由に連想し, 出力文を生成するため, 連想 によっては自然な文とならない可能性がある .

評価データを入力とし，提案した連想応答手法を用い て出力した応答文を 3 名にて評価した . 被験者は本シス テムと関係のない理系の男子学生 (20 代前半) であった . 評価者は入力文と応答文を同時に観察し，作成された応 答文を「常識」「非常識」に分類する評価を行った . 評価 基準は光れ光れ 3 名中 2 名以上が常識としたときを「○」, 3 名中 1 名が常識としたときを $\triangle \Delta, 3$ 人全員が非常識 としたときを「メ」とした .これにより，出力文が自然 な文章か不自然な文章かを評価する．

場所連想，形容詞連想，話題転換連想の关れぞれに対 して評価を行った結果を图 10 に示す.「○」と「 $\triangle 」 を$ 合わせた割合を精度とすると，場所連想は $80 \%$, 形容詞 連想は $74 \%$ ，話題転換連想は $71 \%$ の精度となった。 


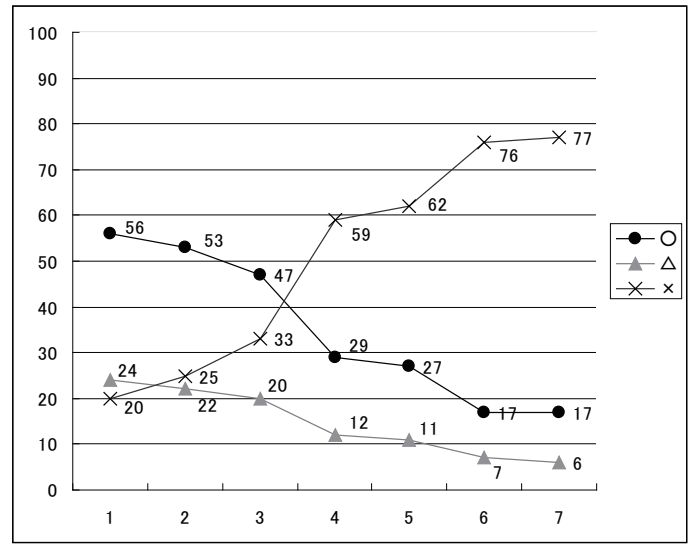

図 11 関連度の高さ順による組み合わせ評価

表 16 場所連想の成功例と失敗例

\begin{tabular}{|l|l|l|}
\hline & 入力文 & 出力文 \\
\hline 成功例 & $\begin{array}{l}\text { カジノへ } \\
\text { 行きました }\end{array}$ & ポーカーで \\
& 遊びましたか? \\
\hline \multirow{3}{*}{ 失敗例 } & 図書館へ & 蔵書を \\
& 行きました & 閲覧してきたのですか? \\
\cline { 2 - 3 } & 教会を & 聖書を \\
& 訪れました & 信仰してきたのですか? \\
\hline
\end{tabular}

また, 提案手法では名詞と動詞 (または形容語) の組 み合わせ候補のうち, 入力文の語彙と最も関連性の高い 語の組でシステム構築を行っている. 乥こで他の候補語 の組についての調査を行った．場所連想を例として用い， 関連度が最も高い語の組を第 1 候補とし, 更に第 2 位か ら第 7 位の語の組において評価を行った（図 11).

図 11 より, 入力文の語彙と関連性が高い語の組である ほど精度が高いことがわかる. 并こで, 候補として用い る際の順位付けとして関連度を用いることは適当である と考えられる.

場所連想の成功例，失敗例を表 16 に示す.

失敗例として，「図書館へ行きました」という入力文に おいて, 場所語「図書館」から得られる場所主体語に適 切な語「本」があるにも関わらず，「図書館」との関連度 が最も高い「蔵書」が選択された．弚のため, 杂倠談のよ うな会話ではあまり用いられない「蔵書」を用いた応答 文が生成されてしまい, 不自然な文と感じさせる結果と なった「蔵書」という知識は「図書館」という場所知識 の中では常識に入ると考える．つまり，常識知識 (場所) データベースは正しく格納されている．しかし，この「蔵 書」という言葉を杂倠談で扱うには硬い表現と考えられる ため, 常識データベースでは必要な情報であるにも関わ らず, 杂倠談システムでは除かれるべき言葉が存在してい ることがわかった．また，「教会を訪れました」という入 力文においては，連想によって，「聖書」や「信仰する」 を導いたものの, 教会で行う具体的な行動に結びつかず，
表 17 形容詞連想の成功例と失敗例

\begin{tabular}{|l|l|l|}
\hline & 入力文 & 出力文 \\
\hline 成功例 & 動物園で & 象は \\
& 大象を見ました & 大きいですよね \\
\hline \multirow{3}{*}{ 失敗例 } & 洞窟で & コウモリは \\
& コウモリを見ました & 有名ですよね \\
\cline { 2 - 3 } & 喫茶店で & 珈琲は \\
& 珈琲を飲みました & 黑かったですか? \\
\hline
\end{tabular}

表 18 話題転換連想の成功例と失敗例

\begin{tabular}{|l|l|l|}
\hline & 入力文 & 出力文 \\
\hline 成功例 & 喫茶店でケーキを & 紅茶を \\
& 食べました & 飲みましたか? \\
\hline \multirow{5}{*}{ 失敗例 } & 教会で聖書を & 十字架を \\
& 読みました & 信仰しましたか? \\
\cline { 2 - 3 } & 劇場で映画を & 証明を \\
& 見ました & 鑑賞しましたか? \\
\hline
\end{tabular}

弚れらを用いた適切な応答が作成できなかった．このよ うに，場所に存在する物 (場所主体語) や行動 (場所目 的語) を組み合わせるだけでは適切な応答ができない入 力文が存在することがわかった .

また，形容詞連想の成功例，失敗例を表 17 に示す．

形容詞連想の失敗例の大きな要因は, 名詞を適切に形 容する語が少ないことが挙げられる . 形容する語を取得 する方法として , 感覚判断システムと大規模格フレーム システムを複合的に用いたが, 対象とする単語によって は適切な形容語をほとんど取得できない場合もある . 例 えば,「洞窟でコウモリを見ました」という入力文に対し て, 対象とする単語「コウモリ」から取得した形容語に は適切な形容語がほとんど存在しておらず, 弚の中で最 も関連度が高かったのは，「有名」であった，光のため， 適切な形容語を関連度に閾值を設けるなどの処理によっ て判断し, 適切な形容語が存在しない場合は連想を行わ ないという処理が必要になると考えられる.

また，形容詞連想においても，場所連想での失敗要因 と同樣の関連度による失敗が見られた．例えば，「喫茶店 でコーヒーを飲みました」という入力文に対して，「コー ヒー」から得られる形容語のうちに適切な形容語「美味 しい」が取得できたにも関わらず, 関連度が最も高い「黑 い」が取得されたため，不自然な応答文となった . 形容す る語の中でも，「色」のように，物を表現する上で当然の 事柄に関しては会話において非常に優先度が低いと考え られる・よって，このような形容語について整理し，応答 候補としての優先度を低くする必要があると考えられる．

次に, 話題転換連想の成功例，失敗例を表 18 に示す. 話題転換連想の失敗の要因としては, 場所に存在する 物 (場所主体語) に対する適切な行動が場所目的語にあ まり存在しなかったことによる．例えば，「教会で聖書を 読みました」という入力文に対して「十字架」を連想す 
ることができたものの，「十字架」に対する適切な行動が 場所目的語に存在せず, 光れらを用いた適切な応答が作 成できなかった。このように，場所に存在する物（場所 主体語) や行動 (場所目的語) を組み合わせるだけでは 適切な応答ができない入力文が存在することがわかった .

このように, 光れ光れの手法においては改善点や追究 すべきところが残されているものの，場所連想は $80 \%$ ， 形容詞連想は $74 \%$, 話題転換連想は $71 \%$ の精度という評 価を得ることができた .

\section{5. ま と め}

本論文では機械による会話について考察し，目的のな い会話である杂倠談における機械からの応答について整理 を行った .また，応答を行うための一般的な応答処理方 法を提案し, 更に会話内容から常識的に連想してより豊 かな応答を行う連想応答についての提案を行った . 提案 手法に基づいて構筑したシステムにより検証を行った結 果, 場所連想は $80 \%$, 形容詞連想は $74 \%$, 話題転換連想 は $71 \% の$ 精度という評価を得た。

提案手法を用いて応答文を作成することにより，会話 を促進し，弚の応答によって，機械か常識を持ち，会話 の内容を理解していることをアピールすることができる . しかし, 提案手法の応答文を出現させる条件・順番・状 態については更に議論を重ねる必要がある. 定型的な応 答文, 質問文の中に適切な条件と割合で提案手法の応答 文を出現させることにより,より自然に近い応答システ ムとなることが期待される .

\section{謝辞}

本研究の一部は, 科学研究費補助金 (若手研究 (B) 24700215) の補助を受けて行った .

\section{$\diamond$ 参 考 文 献 $\diamond$}

[秋葉 04] 秋葉 友良, 藤井 敦, 伊藤 克且 : 質問応答における常識 的な解の選択と期待効用に基づく回答群の決定, 情報処理学会研 究報告, NL-163, pp. 131-138 (2004)

[荒木 07] 荒木 孝允, 奥村 紀之, 渡部 広一, 河岡司 : 比較対象概念 の共通属性を重視する動的関連度計算方式, 同志社大学理工学研 究報告,Vol.48,No.3 (2007)

[col 05] COLUMBUS 21 ENGLISH COURSE 1,2,3, 光村図書 (2005) [Cro 05] NEW CROWN ENGLISH SERIES 1,2,3, 三省堂 (2005)

[江頭 12] 江頭 勇佑, 柴田 知秀, 黑橋 禎夫 : 杂隹談対話システムに おける強化学習を用いた応答生成モジュールの選択, 言語処理学 会第 18 回年次大会発表論文集 D3-7, pp. 654-657 (2012)

[Havasi 07] Havasi, C., Speer, R., and Alonso, J.: ConceptNet3: a Flexible, Multilingual Semantic Network for Common Sense Knowledge., In Recent Advances in Natural Language Processing (2007)

[H.Kauts 86] H.Kauts, and J.F.Allen, : Generalized plan recognition, Proceedings of the AAAI'86, pp. 32-37 (1986)

[hor 05] NEW HORIZON English Course 1,2,3, 東京書籍 (2005)

[飯田 06] 飯田 善久, 梅津 圭介: アスペクト指向プログラミングに よる旅館予約システムの開発, 成蹊大学理工学研究報告, Vol. 43, No. 1, pp. 9-15 (2006)

[芋野 11] 芋野美紗子, 吉村 枝里子, 土屋 誠司, 渡部広一: 概念 ベース精錬のための属性追加手法の提案, 信学技報 AI2010-58, pp. 1-6 (2011)

[稲葉 09] 稲葉 通将, 磯村 直樹, 鳥海 不二夫, 石井 健一郎: 意味 ネットワークによる非タスク指向型対話システムの評価, 信学技 報 AI2008-69, Vol. 108, No. 456, pp. 29-34 (2009)

[村本 11] 村本 晃一, ジェプカ ラファウ, 荒井 健治 : 自動生成さ れた常識的知識を表現する文の自然性判定, 人工知能学会第 25 回全国大会，3C2-OS19-8 (2011)

[J.Weizenbaum 65] J.Weizenbaum, : ELIZA - A Computer Program For the Study of Natural Language Communication Between Man and Machine, Communications of the Association For Computing Machinery, Vol. 9, No. 1, pp. 36-45 (1965)

[笠原 97] 笠原要, 松澤和光, 石川勉 : 国語辞書を利用した日常語 の類似性判別, 情報処理学会論文誌, Vol. 38, No. 7, pp. 1272-1283 (1997)

[Kaufmann 90] Kaufmann, M.: DARPA(1990), Proceedings of the Third DARPA Speech and Natural Language Workshop (1990)

[Kaufmann 91] Kaufmann, M.: DARPA(1991), Proceedings of the Forth DARPA Speech and Natural Language Workshop (1991)

[Kaufmann 92] Kaufmann, M.: DARPA(1992), Proceedings of the Fifth DARPA Speech and Natural Language Workshop (1992)

[河原 06] 河原 大輔, 黑橋 禎夫 : 高性能計算環境を用いた Web か らの大規模格フレーム構築, 情報処理学会 自然言語処理研究会 171-12, pp. 67-73 (2006)

[川島 05] 川島 貴広, 石川勉 : 言葉の意味の類似性判別に関する シソーラスと概念ベースの性能評価, 人工知能学会論文誌, 20 巻 5 号 B, pp. 326-336 (2005)

[木村 01] 木村泰知, 荒木 健治, 桃内 佳雄, 栃内 香次 : 遺伝的アル ゴリズムを用いた帰納的学習による音声対話処理手法, 電子情報 通信学会論文誌 Vol.J84-D2, No. 9, pp. 2079-2091 (2001)

[Maedche 01] Maedche, A. and Staab, S.: Ontology learning for the Semantic Web, Intelligent Systems, IEEE, Vol. 16, No. 2, pp. 72-79 (2001)

[MITa] MIT, : ConceptNet5, http://conceptnet.media.mit.edu/

[MITb] MIT, : Open Mind Common Sense, http://openmind.media.mit.edu/

[岡本 01] 岡本 潤, 石崎 俊 : 概念間距離の定式化と既存電子化辞 書との比較, 自然言語処理, Vol. 8, No. 4, pp. 37-54 (2001)

[奥村 07] 奥村 紀之, 土屋 誠司, 渡部広一, 河岡司 : 概念間の関連 度計算のための大規模概念べースの構築, 自然言語処理, Vol. 14, No. 5, pp. 41-64 (2007)

[one 05] ONE WORLD English Course 1,2,3, 教育出版 (2005)

[柴田 09] 柴田 雅博, 富浦 洋一, 西口 友美: 杂隹談自由対話を実現 するための WWW 上の文書からの妥当な候補文選択手法, 人工 知能学会論文誌, Vol. 24, No. 6, pp. 507-519 (2009)

[條原 02] 篠原 宜道, 渡部広一, 河岡司: 常識判断に基づく会話 意味理解方式, 言語処理学会第 8 回年次大会発表論文集, A2-9, pp. 275-278 (2002)

[杉本 03] 杉本二郎, 渡部広一, 河岡司: 概念ベースを用いた常 識場所判断システムの構築, 情報処理学会自然言語処理研究会資 料, 2003-NL-153, pp. 81-88 (2003)

[sun 05] SUNSHINE ENGLISH COURSE 1,2,3, 開隆堂 (2005)

[高柳 11] 高柳 俊祐, 中山 敬太, 石川勉 : ペット型ロボットを想 定した知識処理利用の杂倠談型自由対話システム, FIT2011, E-011 (2011)

[谷垣 95] 谷垣宏一,チャクラボルティゴウタム, 白鳥 則郎 : 自然 言語インタフェースに基づいた電子秘書システムの構成, 情報処 理学会研究報告, マルチメディア通信と分散処理研究報告 95(22), pp. 73-78 (1995)

[德久 06] 德久 良子, 寺嶌立太 : 非課題遂行対話に関する研究動 向 〜雑談システムへの接近〜, 人工知能学会 言語・音声理解と 対話処理研究会 (SIG-SLUD-A503-4) (2006)

[tot 05] TOTAL ENGLISH 1,2,3, 学校図書 (2005)

[土屋 02] 土屋 誠司, 小島一秀, 渡部広一, 河岡 司: 常識的判断 システムにおける未知語処理方式, 人工知能学会論文誌 Vol.17, No. 6, pp. 667-675 (2002)

[渡部 04] 渡部広一, 堀口 敦史, 河岡司: 常識的感覚判断システム における名詞からの感覚想起手法, 人工知能学会論文誌, Vol. 19, No. 2, pp. 73-82 (2004)

[渡部 06] 渡部 広一, 奥村 紀之, 河岡司 : 概念の意味属性と共起 情報を用いた関連度計算方式, 自然言語処理, Vol. 13, No. 1, pp. 53-74 (2006) 
[池原 97] 池原 悟, 宮崎 正弘, 白井 諭, 横尾 昭男, 中岩 浩巳, 小 倉 健太郎, 大山芳史, 林 良彦: 日本語語彙体系, 岩波書店 (1997)

〔担当委員 : 堂坂 浩二〕

2012 年 6 月 28 日 受理

著者紹介
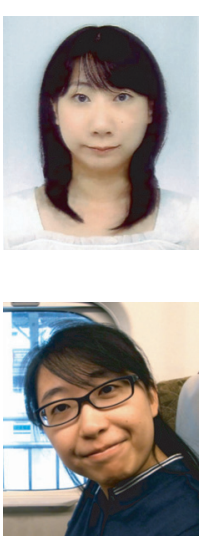

吉村 枝里子

2004 年同志社大学工学部知識工学科卒業. 2006 年同大学 院工学研究科知識工学専攻博士前期課程修了. 2009 年同 大学院工学研究科知識工学専攻博士後期課程修了. 同年, 同志社大学理工学部研究員. 博士 (工学) . 主に知識処理, 意味解釈, 会話処理の研究に従事. 言語処理学会, 情報処 理学会各会員.

芋野 美紗子

2009 年同志社大学工学部知識工学科卒業. 2011 年同大学 院工学研究科情報工学専攻博士前期課程修了. 同大学院工 学研究科情報工学専攻博士後期課程在学. 主に, 概念処理 の研究に従事.言語処理学会会員。

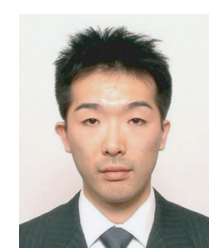

土屋 誠司(正会員)

2000 年同志社大学工学部知識工学科卒業. 2002 年同大学 院工学研究科知識工学専攻博士前期課程修了. 同年, 三洋 電機株式会社入社. 2007 年同志社大学大学院工学研究科 知識工学専攻博士後期課程修了. 同年, 德島大学大学院ソ シオテクノサイエンス研究部助教. 2009 年同志社大学理 工学部インテリジェント情報工学科助教 . 2011 年同准教 授. 博士 (工学) . 主に, 知識処理, 概念処理, 意味解釈 の研究に従事。言語処理学会, 情報処理学会, 日本認知科 学学会, 電子情報通信学会各会員

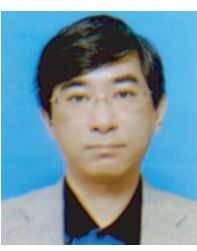

渡部 広一(正会員)

1983 年北海道大学工学部精密工学科卒業. 1985 年同大 学院工学研究科情報工学専攻修士課程修了.1987 年同精 密工学専攻博士後期課程中途退学. 同年, 京都大学工学部 助手. 1994 年同志社大学工学部専任講師. 1998 年同助教 授. 2006 年同教授.工学博士.主に, 進化的計算法, コ ンピュータビジョン, 概念処理などの研究に従事. 言語処 理学会, 情報処理学会, 電子情報通信学会, システム制御 情報学会, 精密工学会各会員. 